\title{
Fictional Turn in Translation Studies
}

\author{
Dong-mei $\mathrm{Ma}^{1,2}$ \\ ${ }^{1}$ College of Foreign Languages and Cultures \\ Sichuan University \\ Chengdu, China \\ ${ }^{2}$ Foreign Language School \\ Lanzhou University of Technology \\ Lanzhou, China \\ meredith310@126.com
}

\begin{abstract}
Fictional turn is a very important trend in translation studies in 1990s. It refers to the move in the discipline that signaled the incorporation of fictional-theoretical parameters as a source of theorization on translation. This paper gives a brief introduction to the trend and outlines relevant literatures both at home and abroad. Then a case study is presented as an illustration of fictionalization of translation and approaching fiction as a source of translation theorization. It is concluded that fictional turn in translation studies does not only offer new possibilities for translation studies, but also provides illuminations for translation teaching.
\end{abstract}

Keywords-fictional turn; fictional-theoretical parameters; fictionalization of translation

\section{INTRODUCTION TO FICTIONAL TURN IN TS}

Fictional turn put forward in the 1990s is one of the many turns in translation studies. It must be noted that the turns in translation studies such as technological turn, ethical turn, cognitive turn just refer to the shift of perspective rather than the shift of research focus, so is the fictional turn. Fictional turn in translation studies emerged with the poststructuralist dissolution of generic boundaries that has characterized literary theory and cultural studies and its redefinition of theory. Boundaries between traditionally exclusive categories including fiction and nonfiction were redesigned. Argentine writer and critic Jorge Luis Borges inaugurated the practice of theorizing through a seemingly fictional text that actually fictionalizes the theoretical concerns of the writer. According to Borges, all fictional works contain a theoretical component just as all theories possess a fictional character. The incorporation of fiction as a medium of theoretical speculation has broadened the horizons of critical and literary theory. In the field of translation studies, the study of fiction as a source of translation theorization was no doubt one of the main contributions to translation theory in the 1990s. [1] The Brazilian critic Else Ribeiro Pires Vieira calls such practice the "fictional turn" in translation studies, defining it as the move in the discipline that signaled "the incorporation of fictionaltheoretical parameters" as a source of theorization on translation and other hermeneutical processes in the paper "(In) visibilities in Translation: Exchanging Theoretical and

Supported by Research Project of Higher Education Institutes in Gansu Province (2016A-015)/ 2016's Provincial Educational Science Program during $13^{\text {th }}$ Five-Year Plan Period in Gansu Province (GS[2016]GHB0237) /2017's English Teaching Reform Program co-sponsored by Gansu Higher Education Institutes and Shanghai Foreign Language Education Press (2017(37))

\section{Fictional Perspectives”.[2]}

The fictional turn in translation studies is characterized by a twofold movement. On the one hand, some theorists and novelists fictionalize translation by using translation as a theme for fictional writing. For example, world-famous writers such as Jorge Luis Borges, João Guimarães Rosa, Mario de Andrade, Julio Cortázar, Jose Saramogo, Italo Calvino, Gabriel Garcia Márquez and some outstanding figures in their own regions such as the Argentine Rodolfo Walsh, the Brazilian Moacyr Scliar and the Hungarian Dezso Kosztolanyi all expressed theoretical concerning through their storylines. On the other hand there is a movement of critics and theorists who approach fiction as a source of translation theorization. Scholars such as Adriana S. Pagano, Rosemary Arrojo, Christopher Larkosh and Thomas O. Beebe are greatly interested in exploring the translational representations in the fictions. Rosemary Arrojo once said that "If we are willing to consider the notion of theory more broadly and in terms that would be compatible with the etymology of theoria, that is, as a way of seeing or looking, we are likely to learn a great deal on translation and translation-related questions from fictional narratives, whose plots usually defend or side with a certain point of view and play out some of its most impacting consequences, offering unique opportunities for reflection that can be potentially more insightful than those associated with what specialists tend to classify as 'real' theory".[3] She plunges into the works of Jorge Luis Borges and João Guimarães Rosa, exploring the instability of meanings and the notion of equivalence and faithfulness present in Borges' work; She continues such exploration in her analyzing of the works of many other authors from different backgrounds. For example, she studied the marginalized status of translators and translations in Rodolfo Walsh's work. Thomas O. Beebe also put in an article that "if fiction is distinguished from other forms of discourse in its propensity to 'play' with the given ideologemes of its cultural context," that is, if fiction can be freer and more creative in the ways in which it conveys or represents concepts and values, then, "the best place to trace the ideology of translation is through its fictional embodiment.”[4]

\section{Literature REVIEW ON FICTIONAL TURAN IN TS}

In consonance with the line of argument mentioned above, scholars with various agendas and from multiple cultural and scholarly backgrounds show their interest in representations of 
translators and translation-related issues in fiction. They have their works on this topic published in leading international journals. Thomas O. Beebee examined the translational representation in the work Love in Two Languages of the Maghrebine writer Abdelkebir Khatibi; Brian Mossop published the article "The Image of Translation in Science Fiction and Astronomy" in Translator, focusing on the astronomers and science fiction writers who discuss the conditions for translatability such as universal physical, logical and mathematical constants.[5]Translation and Power edited by Maria Tymoczko and Edwin Gentzler in 2002 collected two pieces concerning the fictional turn in translation studies. One is "Writing, Interpreting, and the Power Struggle for the Control Meaning” by Rosemary Arrojo, analyzing fiction by Franz Kafka, Jorge Luis Borges and Dezso Kosztolanyi in terms of a Nietzschian "will to power". The other is "Translation as Testimony: On Official Histories and Subversive Pedagogies in Cortázar” by Adriana Pagano, who interweaves Cortázar's displacement with the movement of translation. Strumper-Krobb published the article "The Translators in Fiction" in Language and Intercultural Communication;[6]Japanese scholar Judy Wakabayashi examined the representations of translators and translation in Japanese fiction;[7]Dirk Delabastita and Rainier Grutman edited a special issue "Fictionalizing Translation and Multilingualism” for Linguistica Antverpiensia, including Wozniak's 'Future Imperfect: Translation and Translators in Science Fiction Novels and Films” [8]and Baer's “Translating the Transition: The Translator-Detective in Post-Soviet Fiction”.[9]In the introduction, Dirk Delabastita and Rainier Grutman recognize that in recent years, there have been "a growing number of fictional representations of translation and multiligualism". Rita Wilson published the article "The Fiction of the Translator" in Journal of Intercultural Studies; [10] Edwin Gentzler in his Translation and Identities in Americas: New Directions in Transaltion Theory also focused on the fictional turn in translation studies, exploring the translationrelated theme in the works of Gabriel Garcia Márquez, Jorge Luis Borges and Mario Vargas Llosa. Ben-Ari discussed representations of translators in popular culture in Translation and Interpreting Studies;[11]Judy Wakabayashi published another article in 2011 in Translation Studies, exploring the nature and spectrum of relationships between authors and translators as identified in a corpus of fictional representations and maintaining the idea that the fictional constructions have the potential to offer theoretical insights into the creative nature and limits of translatorship and its overlapping with authorship and also to question the superiority usually ascribed to the latter.[12]Rosemary Arrojo published several articles exploring fictional representations of the work of translators. In 2018 she published an anthology of eight papers named Fictional Translators-Rethinking Translation through Literature to examine the prevailing clichés associated with translators and their practice. She holds the idea that "In contrast to the usually sober discourse of scholarly studies, fictional texts focusing on issues of translation, authorship, and reading can provide a more nuanced framed of reference as they introduce us to translator characters that oftentimes reveal their inner struggles while facing the ethical conundrums associated with their work and the relationships they are expected to establish with author and/or reader figures that also have a stake in the process." [13]Arrojo's analysis destabilizes essentialist notions of language and translation.

Three Chinese scholars also show interest in fictional turn in translation studies. Shi Li-lin discussed fictional turn by giving introduction to and comment on Adriana Pagano's paper "Translation as Testimony: On Official Histories and Subversive Pedagogies in Cortázar”.[14]Tang Xu-guang in "An Imaginary Translation Metaphor: a Struggle for Controlling the Textual Meaning" gave an introduction to Rosemary Arrojo's metaphorical illustration of the survival of text meaning.[15]He argued that Arrojo's illustration of the alleged power struggle among the writer, reader and translator brings readers a fresh metaphorical perspective but does no good to the translation studies of rationality. Zhu Xiao-ling explored translational metaphors in Cortázar's Letter to a Young Lady in Paris, which metaphorically exposed the translator's gripping narrative of his own failure to protect the author's textual space from his agency and relentless creativity. [16]

In recent years, the exploration of fictional representations of translation has expanded to motion pictures, opening up new and exciting possibilities not only for research on translation but also for its teaching. Several international conferences have been organized. The "First International Conference on Fictional Translators and Interpreters in Literature and Film" was held at the University of Vienna's Centre for Translation Studies in 2011, whose result was the collection of articles Transfiction-Research into the Realities of Translation Fiction, Goldbout's "Fictional Translators in Quebec Novels" [17] included. Two others "Translators and (Their) Authors" and "The Fictions of Translation" were held at Tel-Aviv University, Israel in 2013 and Concordia University in Montreal, Canada, in 2015 respectively.

\section{CASE StUdies-Rodolfo Walsh'S FoOtnote}

\section{A. Brief Introduction to Footnote}

Footnote was a poignant short story by the Argentine Rodolfo Walsh entitled "Nota al pie". The quotation in this paper is the English version provided by Rosemary Arrojo. In Footnote, Walsh introduced a lonely and unhappy translator Leon who spent most of his life perfecting the art of being invisible and just killed himself in the cheap boarding house where he lived. He wrote a letter to his boss and editor Otero before killing himself. When Otero came to identify the body at the request of the police the housekeeper handed him the letter, but he refused open it because he wants to imagine the dead man's version. Therefore, the text is made up of two narratives. Otero's imagined version occupied the main body while the first-person narrative by the translator was arranged at the bottom of the page, constituting the footnote which occupies more and more space on each page up to the last one when it actually takes over and replaces the main narrative. In the footnote, Leon described the oppression and sufferings he experienced in his translation career. 


\section{B. Fictionalization of Theory in Footnote}

Arrojo put in one of her article that "the reading of fiction on the theme of translation, rather than merely confirming or echoing the arguments and conclusions of philosophers and translation studies scholars, can illuminate certain issues that are rarely explored in more conventional scholarship. [18]

The opposition between the main body and the footnote symbols the power relation between the editor who holds the almost exclusive power and the subservient translator who is usually related to a marginalized position. We can learn from the main body of the text that for Otero, being invisible, erasing one's personality is in fact the "hardest of all the secrets" a translator need to learn: "to go unnoticed, to write like another and not let anybody know that"[19] While the translator must accept a passive role in the production of translations, it is the publishing house's "mission" to nourish the dreams of the people and build a culture for them, even against themselves" [20]. From the footnote of the text, we learn that the translator cannot choose the work to translate. His first assignments were detective fiction which he shows no enthusiasm. Under the guidance of Otero, the translator tried to curb his authorial impulse. Gradually, he felt more and more apathetic and exhausted because of "feeling inhabited by another, who was often an imbecile: to lend your head to a stranger and only recover it when it was worn out, empty, devoid of ideas, useless for the rest of the day"[21]. He thought that manual laborers were required to "rent their hands," the translator had to "rent his soul".

Leon was not only invisible and impotent as a translator and as intellectual, but socially isolated as well. We know from the text that he had no peers, no colleagues, no one with whom he could discuss his work or exchange ideas, with perhaps the exception of his old dictionary. In the society with highly stratified social structure, the translator found himself been alienated from the laborers whom he lived with and distant form the editor for whom he worked. What's worse, he was also economically exhausted. Though he worked more and more hours, he made less and less money than his previous manual laboring. Before he decided to kill himself, he was forced to pawn his typewriter. All he had were two outfits and a dictionary. In the end, alone and physically and emotionally drained after years of hardship and total dedication to an activity of which he could no longer be proud, he decided to end his life.

The characterization of the image of translator as subservient and invisible servant constitutes a memorable space for the exploration of the hierarchical opposition in the activity of translating. In spite of the tragic end, the translator's voice was finally heard, which is symbolized by the fact that the footnote gradually took the place of the main text as the storylines developed and the editor's coming to visit the dead man at the request of the police although he was unwilling to do so.

The story in Footnote constitutes a space for reflection on the practice of translation and on the translators' in (visibility). It is widely known that the translator scholar Lawrence Venuti is concerned with one of the central focuses of contemporary translation studies-the recognition and exploration of the translator's visibility and its consequences. He explored this issue in his well-known book The Translator's Invisibility-A History of Translation. In his another book The Scandals of Translation-Towards an Ethics of Difference, he exposed that the scandals of translation are cultural, economic and political and basically refer to the marginal status of the translator's activity. For Venuti, perhaps "the greatest scandal of translation" is that "asymmetries, inequalities, relations of domination and dependence exist in every act of translating."'[22]

The issues addressed in Venuti's scholarly texts are also represented by Walsh's story. In spite of the different genres, goals and conventions, the reading of such stories can enrich and deepen our understanding of the scholarly texts. Moreover, Footnote offers us a portrait of the translator that is multilayered and more nuanced than what we usually find in scholarly texts.

\section{CONCLUSION}

Jacques Derrida once defended literature as a privileged site for the kind of reflection generally associated with philosophy or theory. For him, "the thinking that takes place in philosophy" is not "confined to technical philosophy, or to the canonical history of philosophy," but can also be found "in many other places, in law, linguistics, and psychoanalysis. Above all, the thinking that occurs in philosophy communicates in a very special way for Derrida himself with literature.”[23] According to Rosemary Arrojo, fiction offers a plethora of perspectives and angles that cannot be found in other genres. Because of its multiple resources and the liberties it is allowed to take in the construction of plots and characters, fiction can portray not only lively interpretations of theoretical constructs, but also emotional reactions to such constructs in a unique combination that often includes elements from the author's biography as well as clashing ideological positions that can be defended in the name of different characters. [24] Therefore, fictionalization of translation theories can be more insight than what scholars tend to classify as real theory. Exploring theoretical representations in translation-related fictions can not only deepen our understanding of relevant issues, it also offers new possibilities for translation studies. Besides, the approach is a quite effective way in translation teaching because with their creative resources such as colorful and contradictory characters, humorous or unpredictable intrigues, surprising events and revelations, dramatic twists and turns, fictions can effectively elicit the interest of nonspecialists or beginning learners in theoretical problems.

\section{REFERENCES}

[1] Pagano, A. S. "Translation as Testimony: On Official Histories and Subversive Pedagogies in Cortazar,” In M. Tymoczko and E. Gentzler (eds.) Translation and Power. Amherst: University of Massachusetts Press, 2002, pp. 80-98.

[2] Vieira, E.R.P. “(In) visibilities in Translation: Exchanging Theoretical and Fictional Perspectives,” ComTextos, volume 6, 1995, pp. 50-68.

[3] Arrojo, R. Fictional Translators-Rethinking Translation through Literature, London \& New York: Routledge, 2018, p.3.

[4] Beebe, T.O. "The Fiction of Translation: Abdelkebir Khatibi's Love in Two Languages,” Substance, volume 23, 1994, pp. 63-78. 
[5] Mossop, B. "The Image of Translation in Science Fiction \& Astronomy,” Translator, volume 2, 1996, pp. 1-26.

[6] Strumper-Krobb, S. "The Translator in Fiction," Language and Intercultureal Communication, volume 3, 2003, pp. 115-121.

[7] Wakabayashi, J. "Representations of Translators and Translation in Japanese Fiction," in Delabastita, D. and R. Grutman, (eds.) "Fictionalizing Translation and Multilingualism," Linguistica Antverpiensia, volume 4, 2005, pp.156-169.

[8] Wozniak, M. "Future Imperfect: Translation and Translators in Science Fiction Novels and Films," in D. Delabastita and R. Grutman (eds.), "Fictionalizing Translation and Multilingualis m," Linguistia Antverpiensia, volume 4, 2005, pp.345-361.

[9] Baer, B.J. "Translating the Transition: The Translator-Detective in PostSoviet Fiction," in D. Delabastita and R. Grutman (eds.), "Fictionalizing Translation and Multilingualism," Linguistia Antverpiensia, volume 4, 2005, pp. 243-254.

[10] Wilson, R. "The Fiction of the Translator," Journal of Intercultural Studies, volume 28, 2007, pp. 381-395.

[11] Gentzler, E. Translation and Identity in the Americas-New Directions in Translation Theory. London \& New York: Routledge, 2008.

[12] Wakabayashi, J. "Fictional Representations of Author-Translator relationships,” Translation Studies, volume 4, 2011, pp, 87-102.

[13] Arrojo, R. Fictional Translators-Rethinking Translation through Literature, London \& New York: Routledge, 2018, p.1.

[14] Shi Li-lin, "Fictional Turn in Translation Studies-Comment on 'Translation as Testimony: On Official Histories and Subversive Pedagogies in Cortazar,'” Journal of Mudangjiang College of Education, No.6, 2009, pp. 41-43. (in Chinese)
[15] Tang Xu-guang, “An Imaginary Translation Metaphor: a Struggle for Controlling the Textual Meaning- On Writing, Interpreting, and the Power Struggle for the Control of Meaning: Scenes from Kafka, Borges, and Kosztolanyi,” Journal of Guang xi Teachers Education University, No.2, 2010, pp. 116-120. (in Chinese)

[16] Zhu Xiao-ling. "Translator and his 'rabbits'-Translational Interpretation of Letter to a Young Lady in Paris," East Journal of Translation, No.2, 2016, pp. 69-75. (In Chinese)

[17] Goldbout, P "Fictional Translators in Quebec Novels," in K. Kaindl and K. Spitzl (eds.) Transfiction-Research into the Realities of Translation Fiction, Amsterdam: John Benjamins, 2014, pp. 177-187.

[18] Arrojo, R. Fictional Translators-Rethinking Translation through Literature, London \& New York: Routledge, 2018, p. 35.

[19] Walsh, R. "Nota al pies," in Un Kilo de Oro, Buenos Aires: Ediciones de la Flor, 2008, p. 75.

[20] Walsh, R. "Nota al pies," in Un Kilo de Oro, Buenos Aires: Ediciones de la Flor, 2008, p. 76.

[21] Walsh, R. “Nota al pies," in Un Kilo de Oro, Buenos Aires: Ediciones de la Flor, 2008, p. 94.

[22] Venuti, L. The Scandals of Translation-Towards an Ethics of Difference, London: Routledge, 1998, p. 4.

[23] Caputo, J. D. Deconstruction in a Nutshell - A Conversation with Jacuques Derrida, New York: Fordham University Press, 1997, pp. 5758.

[24] Arrojo, R. Fictional Translators-Rethinking Translation through Literature, London \& New York: Routledge, 2018, pp. 148-149. 